\title{
Analysis of the economic potential of Beach tourism based on the total economic value and spatial interaction with the gravity model method
}

\author{
S Subiyanto \\ Department of Geodesy Engineering, Faculty of Engineering, Diponegoro University \\ Diponegoro University \\ Semarang, Indonesia \\ sawitrisubiyanto66@gmail.com
}

DOI: $10.31364 / \mathrm{SCIRJ} / \mathrm{v} 8.110 .2020 . P 1020816$

http://dx.doi.org/10.31364/SCIRJ/v8.i10.2020.P1020816

\begin{abstract}
Indonesia has made tourism as one of the economic sectors urgent. As an important economic sector, tourism is getting attention serious from the government. Research to determine the economic potential of coastal tourism objects in Pemalang Regency is very necessary to determine priorities and development strategies. The tourist attractions of Widuri and Blendung Beach have beautiful stretches of beach, white sand, clear sea water and interesting underwater biota to see. The potential of these two tourist objects is very good seen from the development of the number of tourist visits that continue to increase. The potential of coastal tourism objects is determined by the total economic value (TV) approach. Tev is calculated by summing the Direct Use Value (DUV) calculated from the Travel Cost Method (TCM) and the Excistence Value (EV) calculated from the Contingent Valuation Method (CVM) data. To find out the demand or supply model, the spatial interaction value of the number of tourist visits is calculated using the Gravity Model approach. TCM respondents are visitors to the area, while CVM respondents are people who use the coastal area such as traders and workers around the area. The sampling technique used is the Non Probability Sampling method. All respondent data have been tested statistically, namely normality, autocorrelation, heteroscedasticity, multicollinearity, validity and reliability. The processing method used is multiple linear regression analysis and the calculation uses Maple 17. The calculation result of the TV value for Widuri Beach is Rp. 35.850.465.345 and Blendung Beach TV Rp. 2.942.445.089. The results of spatial interaction with the Gravity Model indicate that the tourism demand model and the highest spatial interaction are at Widuri Beach. Based on the value of TEV and Spatial Interaction, it shows that Widuri Beach has a better function.
\end{abstract}

Index Terms-Widuri and Blendung Beach, TEV, DUV, EV, Gravity Model

\section{INTRODUCTION}

Pemalang Regency is one of the regencies in Central Java that has a northern coast. Widuri Beach and Blendung Beach are one of the beaches that become tourist attractions. The tourist area of a place can be calculated using direct use value and presence value. Widuri Beach tourism object is one of the water attractions that has interesting places. Blendung Beach which is located in Ulujami District is already well-known among the Pemalang community because with affordable tickets visitors can enjoy the beauty of the beach. Ticket prices and tourist facilities can affect the economic value of an existing tourist area.

According to [9] method of calculating the value of economic environmental and resource benefits can be divided into two groups, based on the assessment of the survey hypothesis and the market value approach. The non-market value approach is carried out to calculate the non-use value, either option value, existence value, inheritance value depending on the area and natural resources to be assessed.

The economic value of the region can be calculated using analysis using the Contingent Valuation Method (CVM) and Travel Cost Method (TCM) approach to determine the WTP Willingness To Pay's (WTP) value given for tourism development and calculate the Total Economic Value (TEV). Economic value zone calculation is a calculation without market value.

This research needs to be done to find out the value of an area that has no market value, so it is necessary to approach the calculation method, making it easier for the government to determine development and development decisions. The potential of these two tourist areas makes this tour has a direct use value obtained from tourists that comes from the costs incurred by tourists and the value of existence that is useful for people around the area by utilizing tourism objects that can be used as business opportunities in their livelihoods. both formal businesses (businesses that get permission from the government and pay taxes) and informal (businesses that do not get a permit by the government and do not pay taxes).

\section{LITERATURE}

\section{A. Typology of Regions}

Most of the literature in the economic valuation field [9] using a economic value's typology in terms of Total Economic Value (TEV). The land area's TEV is assessed from the nonmarket value of the indirect (non-use value) and direct use value (use value). The TEV formula is shown in Equation 1.

$$
T E V=(D U V+I U V+O V)+(B V+E V)
$$

Where TEV (total economic value), DUV (direct use value), IUV (indirect use value), OV (option value), BV (inheritance value) and EV (existence value). 
Information:

1. DUV is the economic value derived from the direct benefits of a resource.

2. IUV is an economic value derived from the potential indirect benefits of an ecosystem.

3. $\mathrm{OV}$ is an economic value derived from the potential direct or indirect benefits of a resource / ecosystem in the future.

4. BV is an economic value derived from the benefits of preserving resources / ecosystems for the benefit of future generations.

5. $\mathrm{EV}$ is an economic value obtained from a perception that the existence of an ecosystem / resource is used or not.

6. TEV is the amount or combination of UV and NUV.

The economic value of the area is all economic values, namely the direct or indirect use value, and the optional or optional value, the value of the existence and inheritance value in an area that does not include the land value and property value contained in the valued area [8]. Regional economic zone value method Willingness To Pay's (WTP) is the highest price a person (consumer) is willing to pay to get a benefit in the form of goods or services, as well as making a benchmark of how much potential customers appreciate the goods or services [10].

\section{B. Travel Cost Method (TCM)}

In determining the demand function for tourist visits, the TCM individual approach uses econometric techniques such as simple regression [11]. The hypothesis is built that the visit to the place of tourism will be strongly influenced by travel costs (travel costs) and is assumed to be negatively correlated, so we get a demand curve that has a negative slope. In [8] simply the above request function can be written as follows:

The equation from TCM based on the calculation guide for textual data processing for frequency of visits can be seen in the equation below:

$$
V=\beta_{o}+\beta_{1} X_{1}+\beta_{2} X_{2}+\beta_{3} X_{3}+\beta_{4} X_{4}+\beta_{5} X_{5}+\beta_{6} X_{6}+\beta_{7} X_{7}
$$

the $\log$ linear form of the function is written :

$$
+\beta_{1} \ln X_{1}+\beta_{2} \ln X_{2}+\beta_{3} \ln X_{3}+\beta_{4} \ln X_{4}+\beta_{5} \ln X_{5}+\beta_{6} \ln X_{6}+\beta_{7} \ln X_{7}
$$

(Calculating consumer surplus:

$$
\text { CS }=0.5 \times \text { Vaverage } \mathrm{x}(\text { TCmax-TCrata) }
$$

Calculate the value of the existence of an area per hectare:

$$
\mathrm{DUV}=C S \times N L
$$

In order to obtain the total benefit (TB), namely the DUV value in each region:

$$
\mathrm{TB}=\mathrm{DUV} \times \mathrm{L}
$$

Where :

$\mathrm{V}=$ Frequency of visits

$\mathrm{X} 1=$ Average Travel Cost

$\mathrm{X} 2=$ Average Age

$\mathrm{X} 3=$ Average Education

$\mathrm{X} 4=$ Average Income
X5 = Average Length of Visit

X6 = Average Alternative

Location

$\mathrm{L}=$ the total area in hectares

\section{Contingent Valuation Method (CVM)}

Contingent Valuation Method (CVM) is a method of survey technique on the value or price that has been asked of residents in the form of provision for commodities that do not have a market such as environmental goods [1].

Equations that can be used in calculating the value of existence (Existence Value / EV) refer to the exercise guide for calculating the regional economic valuation, BPN 2012 quoted in [8]) is as shown in Equation 7.

$$
\text { WTP }=\beta_{0} X_{1}^{\beta_{1}} \mathrm{X}_{2}{ }^{\beta_{2}} \mathrm{X}_{3}{ }^{\beta_{3}} \mathrm{X}_{4}{ }^{\beta_{4}} \mathrm{X}_{5}{ }^{\beta_{5}} \mathrm{X}_{6}{ }^{\beta_{6}} \mathrm{X}_{7}{ }^{\beta_{7}} \mathrm{X}_{8}{ }^{\beta_{8}} \mathrm{X}_{9}{ }^{\beta_{9}}
$$

Transform non-linear models into linear:

$\ln W T P=\beta_{0}+\beta_{1} \ln X_{1}+\beta_{2} \ln X_{2}+\beta_{3} \ln X_{3}+\beta_{4} \ln X_{4}+\beta_{5} \ln X_{5}+\beta_{6} \ln X_{6}$

$$
+\beta_{7} \ln X_{7}+\beta_{8} \ln X_{8}+\beta_{9} \ln X_{9}
$$

Finding the calculated WTP value:

$$
\text { WTP }=\exp \beta_{0} X_{1}^{\beta_{1}} X_{2}{ }^{\beta_{2}} X_{3}{ }^{\beta_{3}} X_{4}{ }^{\beta_{4}} X_{5}{ }^{\beta_{5}} \mathrm{X}_{6}{ }^{\beta_{6}} \mathrm{X}_{7}{ }^{\beta_{7}} \mathrm{X}_{8}{ }^{\beta_{8}} \mathrm{X}_{9}{ }^{\beta_{9}}
$$

Look for the WTPreal value:

WTPreal $=$ WTPmin $+($ decimal value WTPcount $\mathrm{X}$ Magnitude of selected range)

Dim Selected range magnitude $=$ WTPmax - WTPmin

Calculate the Total Benefit (TB), i.e., the existence value (Existence Value, EV)

$$
\mathrm{TB}=\text { WTPreal } \mathrm{x} \mathrm{N}
$$

Where :

$\mathrm{X} 1=$ Average existence

$\mathrm{X} 2=$ Average age

$\mathrm{X} 3=$ Average education

$\mathrm{X} 4$ = Average family size

X5 = Average income

X6 $=$ Average benefits

$\mathrm{X} 7=$ Interests are average

$$
\begin{aligned}
& \mathrm{X} 8=\text { Average conversion } \\
& \mathrm{X} 9=\text { Average participation } \\
& \beta 0-\beta 9=\text { Coefficient } \\
& \text { WTP =Willingness To } \\
& \text { Pay's } \\
& \mathrm{N}=\text { Population } \\
& \text { TB = Total Benefit }
\end{aligned}
$$

\section{Demand Theory}

The law of demand is a conjecture stating that the smaller the price of an item, the higher the demand for that item [3]. The demand function can be seen in the formula below

$$
V=\beta_{o}+\beta_{1} \ln X_{1}+\beta_{2} X_{2}+\beta_{3} X_{3}+\beta_{4} X_{4}+\beta_{5} X_{5}+\beta_{6} X_{6}+\beta_{7} X_{7}
$$

The log-linear form of the function is written in the following form:

$$
\ln V=\beta_{o}+\beta_{1} \ln X_{1}+\beta_{2} X_{2}+\beta_{3} X_{3}+\beta_{4} X_{4}+\beta_{5} X_{5}+\beta_{6} X_{6}+\beta_{7} X_{7}+\beta_{8} X_{8}+X_{9} \beta_{9}
$$

\section{Statistical Test}

\section{Classic Assumption Test}

The classic assumption test needs to be done before performing a regression. This is so that the processed sample data can truly represent the population as a whole [5]. The classic assumption test is an analysis conducted to assess whether in a Ordinary Least Square (OLS) linear regression model there are classic assumption problems. This is done to avoid a biased estimation, considering that not all data can be 
applied regression. Tests conducted in this study were autocorrelation test, multicollinearity test and normality test.

\section{Statistical validity test}

Validity is an index that shows the measuring instrument actually measures what is being measured. In order to know whether the arranged questionnaire is able to measure what we want to measure, therefore, it is necessary to test the correlation between the score of each item (question) and the total score of the questionnaire. [4].

\section{Statistical Reliability Test}

A test is said to have high reliability if the test gives fixed result data even though it is given at different times to the same respondent. Therefore, reliability is often called trustworthiness, reliability, etc. The one-measuring technique consists of odd-even, middle-split, random-split techniques, Kuder Richardson, Hoyd techniques, and Alpha Cronbach.

\section{Spatial Interactions}

In [2], A geographer to measure the strength of spatial interactions between two or more regions.

\section{MATERIALS AND METHODS}

Tool

The equipment used in this study is as follows:

1. Hardware used:
a. RAM 2GB laptop.
b. A printer.
c. Smartphone camera for documentation.
d. Survey form forms (TCM and CVM).

2. Software used:

a. Microsoft Windows 7 computer operating system.

b. Microsoft Office Word 2007 for report generation.

c. Microsoft Office Excel 2007 for data entry and data processing.

d. Maple 17 software to calculate the economic value of the region.

e. ArcGIS 10.3 software for making ZNEK maps and Utility Maps

f. SPSS software to perform statistical tests and test classic assumptions.

g. Mobile Topographer.

Material

Research material in the form of data used in data processing, namely:

A. Spatial Data includes:

1. Map of Pemalang Regency Administration obtained from the Regional Planning and Development Agency.

2. 2017 Pemalang District High Resolution Image from the Regional Planning and Development Agency.

B. Non Spatial Data includes:

1. TCM data includes:

a. Frequency of visits (V)

b. Travel expenses (X1)

c. Age (X2)

d. Education (X3)

e. Revenue per year (X4)

f. Length of visit (X5)

g. Alternative visits / locations (X6)

h. Number of groups (X7)

2. CVM data includes:

a. Willingness to pay (WTP)
b. Value of existence (X1)
c. Age (X2)
d. Education $(\mathrm{X} 3)$
e. Annual income (X4)
f. Number of families (X5)
g. Value of benefits (X6)
h. Value of importance (X7)
i. Conversion value (X8)
j. Value of participation (X9)
k. Value of Satisfaction (X10)

3. Data on the number of annual visitors of Widuri and Blendung Beach Tourism.

4. Interview with the manager to find out the extent and boundaries of tourism in the Department of Tourism and Sports.

\section{Implementation Stage}

The implementation of this research is as follows:

1. Conducting interviews conducted by sampling for TCM data are tourists who visit while for CVM data are respondents who take advantage of Blendung Beach and Widuri Beach Tourism. The withdrawal of respondents was carried out using a non probability sampling method.

2. Topographic survey for making utility maps around the tourist area which is used as research. These general groupings of utilities consist of:

a. Government facilities and public services.

b. Means of

c. Means of worship.

d. Commerce and trade facilities.

e. Recreational and cultural facilities

f. Open space and learning and education.

g. Health facility.

h. Garden facilities

2. Check the completeness of the data

3. Testing TCM and CVM data (Classic assumption test: autocorrelation test, multicolliniarity test, normality test, heterosecurity test)

4. Economic value's calculation of the region (the value of existence and direct use value, also the total value of the area).

Analysis Phase

The analysis phase includes:

1. Analysis of data that is not used

2. Analysis of preliminary TCM and CVM data

3. Analysis of the frequency of visits

4. Potential analysis

\section{RESULTS AND ANALYSIS}

\section{Data that is not used as preliminary TCM and CVM data}

Data that is not used is data that has more residuals away from 0 , meaning that data that has residuals away from 0 are considered blunder data (abnormal data). $92 \%$ of respondents came to Widuri Beach tourism area from within the district, namely Pemalang, the other $8 \%$ came from districts around Pemalang namely Pekalongan, Tegal and Purbalingga. Blendung Beach area 90\% comes from Pemalang Regency and the other 5\% comes from Pekalongan and Tegal Regencies. Initial data from interviews cannot be directly processed must be changed to a number based on the linkert scale. 


\section{Autocorrelation Test Results}

The autocorrelation test method that is often used is the Durbin-Watson test (DW test) with the following conditions:
a. If the DW value is less than 0 to 1.5 , the autocorrelation symptoms occur.

b. If the DW value between 1.5 to 2.5 means that there are no symptoms of autocorrelation.

c. If the DW value between 2.5 to 4 means that there is ambiguity, whether or not there are autokeration symptoms.

The results of the autocorellation test can be seen in TABLE I. The results of the autocorrelation test of the Widuri Beach and Blendung Beach have DW (Durbin-watson) values between 1.5 to 2.5 so that it can be concluded that no autocorrelation symptoms occur.

TABLE I. Autocorrelation test results.

\begin{tabular}{|l|c|}
\hline \multicolumn{1}{|c|}{ Area } & Durbin-watson \\
\hline TCM Widuri & 2.345 \\
\hline TCM Blendung & 2.344 \\
\hline CVM Widuri & 1.865 \\
\hline CVM Blendung & 1.432 \\
\hline
\end{tabular}

\section{Multicollinity Test}

Following the output of the Multicollinearity Test Results in SPSS software can be seen in TABLES II and III.

TABLE II. VIF values of TCM in Blendung and Thistle Beaches.

\begin{tabular}{|c|c|}
\hline $\begin{array}{c}\text { VIF TCM Value of Widuri } \\
\text { Beach }\end{array}$ & $\begin{array}{c}\text { VIF TCM Value of Blendung } \\
\text { Beach }\end{array}$ \\
\hline 1,518 & 1,518 \\
\hline 1,144 & 1,262 \\
\hline 2,134 & 1,703 \\
\hline 2,239 & 1,667 \\
\hline 1,345 & 1,325 \\
\hline 1,336 & 1,145 \\
\hline 1,500 & 1,599 \\
\hline
\end{tabular}

TABLE III. VIF CVM Blendung and Thistle Coastal values.

\begin{tabular}{|c|c|}
\hline $\begin{array}{c}\text { VIF CVM Value in Widuri } \\
\text { Beach }\end{array}$ & $\begin{array}{c}\text { VIF CVM Value in Blendung } \\
\text { Beach }\end{array}$ \\
\hline 1,756 & 1,582 \\
\hline 1,426 & 1,393 \\
\hline 1,372 & 1,261 \\
\hline 1,550 & 1,350 \\
\hline 1,404 & 1,440 \\
\hline 1,932 & 2,077 \\
\hline 2,076 & 2,050 \\
\hline 1,770 & 1,657 \\
\hline 2,242 & 1,891 \\
\hline 1,371 & 1,305 \\
\hline
\end{tabular}

Based on the results of the test output on the SPSS shows that the VIF value on each variable of the two tourist areas both TCM and CVM <10. So it can be concluded that there are no symptoms of multicollinearity.

Normality Test

The normality test explains that the residue must be normally distributed, where if the residue is spread out and in the direction of the diagonal line then the distribution is normal, but if the residue spreads far and does not enter the direction of the diagonal line, then it is not normally distributed.

TABLE IV. Normality test.

\begin{tabular}{|l|c|}
\hline \multicolumn{1}{|c|}{ Kawasan } & Asymp.Sig.(2-tailed) \\
\hline TCM Pantai Widuri & 0.265 \\
\hline TCM Pantai Blendung & 0.565 \\
\hline CVM Pantai Widuri & 0.843 \\
\hline CVM Pantai Blendung & 0.543 \\
\hline
\end{tabular}

Based on the output results obtained normality test results that indicate that the Asymp value. Sig (2-tailed) more than 0.05 . Then it can be concluded that the data is normally distributed.

\section{Test Results for Reliability Validity}

Based on the results of the reliability test of Widuri and Blendung Beach with SPSS can be seen in Figure 1.
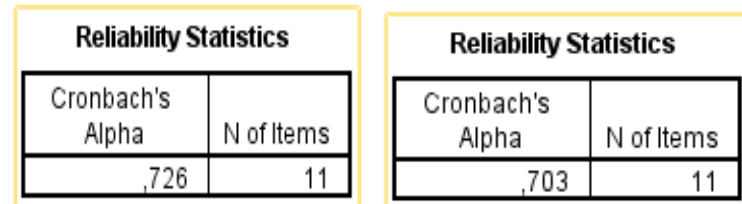

Fig 1. CVM Reliability Test Results a.) Widuri Beach b.) Blendung Beach

Based on the results of the reliability test the value of Cronbach's Alpha Thistle is 0.726, meaning that the answer from the respondent is reliable, meaning that the questionnaire can be used in further research. Based on the results of the reliability test the value of Cronbach's Alpha Blendung is 0.703 which means the answer from the respondent is realiabel meaning the questionnaire can be used in further research.

The value of the corrected item-total correlation can be seen in TABLE $\mathrm{V}$. Based on TABLE $\mathrm{V}$ the value of the corrected item-total correlation is more than the $\mathrm{R}$ value of the table meaning that each variable used is able to measure the WTP value. The corrected item-total correlation value is more than the $\mathrm{R}$ table value meaning that each variable used is able to measure the WTP value.

TABLE V. Validity Test of CV Thistle and Blendung.

\begin{tabular}{|l|c|c|c|c|c|}
\hline Parameter & $\begin{array}{c}\text { Corrected } \\
\text { item- total } \\
\text { correlation } \\
\text { Widuri }\end{array}$ & $\begin{array}{c}\mathbf{R} \\
\text { tabel }\end{array}$ & $\begin{array}{c}\text { Corrected } \\
\text { item-total } \\
\text { correlation } \\
\text { Blendung }\end{array}$ & $\begin{array}{c}\mathbf{R} \\
\text { tabel }\end{array}$ & ormatio \\
\hline WTP & 0.24 & 0.18 & 0.47 & 0.18 & $\begin{array}{c}\text { Vali } \\
\mathrm{d}\end{array}$ \\
\hline $\begin{array}{l}\text { Value of } \\
\text { Existence }\end{array}$ & 0.60 & 0.18 & 0.51 & 0.18 & $\begin{array}{c}\text { Vali } \\
\mathrm{d}\end{array}$ \\
\hline Age & 0 & 0 & 0 & 0.18 & $\begin{array}{c}\text { Vali } \\
\mathrm{d}\end{array}$ \\
\hline Education & 0 & 0 & 0 & 0.18 & $\begin{array}{c}\text { Vali } \\
\mathrm{d}\end{array}$ \\
\hline $\begin{array}{l}\text { Revenue } \\
\text { per year }\end{array}$ & 0 & 0 & 0 & 0.18 & $\begin{array}{c}\text { Vali } \\
\mathrm{d}\end{array}$ \\
\hline $\begin{array}{l}\text { Number of } \\
\text { Family }\end{array}$ & 0 & 0 & 0 & 0.18 & $\begin{array}{c}\text { Vali } \\
\mathrm{d}\end{array}$ \\
\hline $\begin{array}{l}\text { Value of } \\
\text { Benefits }\end{array}$ & 0.53 & 0.18 & 0.56 & 0.18 & $\begin{array}{c}\text { Vali } \\
\mathrm{d}\end{array}$ \\
\hline $\begin{array}{l}\text { Value of } \\
\text { Importance }\end{array}$ & 0.62 & 0.18 & 0.52 & 0.18 & $\begin{array}{c}\text { Vali } \\
\mathrm{d}\end{array}$ \\
\hline $\begin{array}{l}\text { Conversion } \\
\text { Value }\end{array}$ & 0.55 & 0.18 & 0.51 & 0.18 & $\begin{array}{c}\text { Vali } \\
\mathrm{d}\end{array}$ \\
\hline $\begin{array}{l}\text { Participatio } \\
\mathrm{n} \text { Value }\end{array}$ & 0.65 & 0.18 & 0.50 & 0.18 & $\begin{array}{c}\text { Vali } \\
\mathrm{d}\end{array}$ \\
\hline $\begin{array}{l}\text { Satisfaction } \\
\text { Value }\end{array}$ & 0.29 & 0.18 & 0.19 & 0.18 & $\begin{array}{c}\text { Vali } \\
\mathrm{d}\end{array}$ \\
\hline
\end{tabular}

www.scirj.org

(C) 2020, Scientific Research Journal

http://dx.doi.org/10.31364/SCIRJ/v8.i10.2020.P1020816

This publication is licensed under Creative Commons Attribution CC BY. 


\section{Influential Variables}

Based on the T-Test TCM variables that affect the frequency of the Widuri Beach visit are the cost, education, alternative locations and the number of groups. Based on TCM variable tables that affect the frequency of Blendung Beach visits are the cost, age, alternative locations and number of groups. Based on the results of the reliability test, the Cronbach's Alpha value is 0.703 , which means that the answers from the respondents are realistic, meaning that the questionnaire can be used in further research.

TABLE VI. TCM Thistle and Blendung T Test.

\begin{tabular}{|c|c|c|c|c|}
\hline Var. & $\begin{array}{c}\boldsymbol{t} \text { Stat } \\
\text { Widuri }\end{array}$ & Specification & $\begin{array}{c}\boldsymbol{t} \text { Stat } \\
\text { Blendung }\end{array}$ & Information \\
\hline X1 & -5.70 & Has an effect & -3.94 & Has an effect \\
\hline X2 & -1.04 & no & -2.06 & Has an effect \\
\hline X3 & -2.69 & Has an effect & -1.74 & no \\
\hline X4 & 1.96 & no & -0.90 & no \\
\hline X5 & 1.36 & no & 1.21 & No \\
\hline X6 & 7.39 & Has an effect & 7.44 & Has an effect \\
\hline X7 & 3.12 & Has an effect & 4.41 & Has an effect \\
\hline
\end{tabular}

Based on the T Test CVM variables that affect the Widuri Beach PAPs are the value of existence, education, number of families and the value of participation. Based on the CVM variable table that affects WTP Blendung Beach are age, income, number of families and conversion value. Variables are said to be influential if the table value is greater than the calculated t stat.

TABLE VII. T Tests on CVM Thistle and Blendung

\begin{tabular}{|c|c|c|c|c|}
\hline Var. & $\begin{array}{c}\boldsymbol{t} \text { Stat } \\
\text { Widuri }\end{array}$ & $\begin{array}{c}\text { Thistle } \\
\text { Specification }\end{array}$ & $\begin{array}{c}\boldsymbol{t} \text { Stat } \\
\text { Blendung }\end{array}$ & $\begin{array}{c}\text { Thistle } \\
\text { Specification }\end{array}$ \\
\hline $\mathrm{X} 1$ & 2.07 & Has an Effect & 1.94 & No Effect \\
\hline $\mathrm{X} 2$ & 1.51 & No Effect & -2.74 & Has an Effect \\
\hline $\mathrm{X} 3$ & 2.40 & Has an Effect & -1.66 & No Effect \\
\hline $\mathrm{X} 4$ & -0.52 & No Effect & 3.75 & Has an Effect \\
\hline $\mathrm{X} 5$ & 9.08 & Has an Effect & 5.17 & Has an Effect \\
\hline $\mathrm{X} 6$ & -1.23 & No Effect & 0.31 & No Effect \\
\hline $\mathrm{X} 7$ & -1.15 & No Effect & 0.58 & No Effect \\
\hline $\mathrm{X} 8$ & -1.48 & No Effect & 2.14 & Has an Effect \\
\hline $\mathrm{X} 9$ & 3.11 & Has an Effect & 0.92 & No Effect \\
\hline $\mathrm{X} 10$ & -0.35 & No Effect & 0.92 & No Effect \\
\hline
\end{tabular}

\section{Total Economic Value}

Based on calculations with maple the total economic value of Widuri and Blendung beaches shown in TABLE VIII.

TABLE VIII. Total economic value of Widuri and Blendung beaches.

\begin{tabular}{|l|c|c|c|}
\hline \multicolumn{1}{|c|}{ Area } & DUV (Rp,) & EV (Rp,) & TEV (Rp,) \\
\hline Widuri & 30.001 .886 .542 & 4.848 .578 .803 & 34.850 .465 .345 \\
\hline Blendung & 1.010 .410 .650 & 1.932 .034 .439 & 2.942 .445 .089 \\
\hline
\end{tabular}

Based on TABLE VIII. It can be seen that the total economic value between the tourist area of Widuri Beach and Blendung Beach is higher. This is because the facilities in the tour are more qualified in the tourist area. Which has a playground and a waterpark. Based on the calculation of some data because the residuals away from 0 are not used in the calculation. Summing DUV and EV. The total economic value of the Widuri Beach area is Rp. 34.850.465.345. While Blendung Beach is Rp. 2.942.445.089.

\section{Tourism Potential}

Spatial interaction is calculated based on the interaction between the research tourism area and the districts within Pemalang Regency.

Spatial interaction tables can be seen in TABLE IX.

TABLE IX. Spatial Interaction of Straight Distance Data

\begin{tabular}{|c|c|c|c|}
\hline District & $\begin{array}{c}\text { Spatial } \\
\text { Interaction } \\
\text { Widuri }\end{array}$ & $\begin{array}{c}\text { Spatial } \\
\text { Interaction } \\
\text { Blendung }\end{array}$ & $\begin{array}{c}\text { Difference } \\
(\%)\end{array}$ \\
\hline Pemalang & 515.53 & 0.00 & 42.65 \\
\hline Taman & 463.56 & 0.00 & 38.35 \\
\hline Petarukan & 167.10 & 22.83 & 9.19 \\
\hline Comal & 16.82 & 51.45 & -9.05 \\
\hline Ampelgading & 15.73 & 7.65 & -0.25 \\
\hline Bantarbolang & 10.89 & 0.00 & 0.90 \\
\hline Randudongkal & 6.41 & 0.00 & 0.53 \\
\hline Bodeh & 5.62 & 5.00 & -0.55 \\
\hline Belik & 2.07 & 0.00 & 0.17 \\
\hline Ulujami & 1.76 & 405.66 & -82.21 \\
\hline Pulosari & 1.61 & 0.00 & 0.13 \\
\hline Moga & 1.15 & 0.00 & 0.09 \\
\hline Watukumpul & 0.49 & 0.00 & 0.04 \\
\hline Warungpring & 0.00 & 0.00 & 0.00 \\
\hline
\end{tabular}

Based on TABLE IX. The biggest interaction based on the population of sub-districts is Pemalang sub-district in Widuri Beach because the distance is not too far and the population is higher than other districts. While in Blendung Beach the biggest interaction with Ulujami sub-district is due to the proximity to tourism. Map of spatial interactions can be seen in Figures 2 and 3.

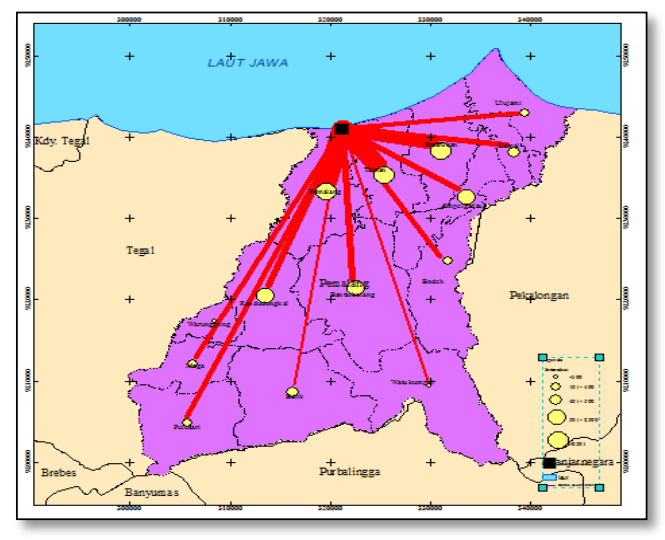

Fig 2 Spatial Interaction of Widuri Beach 


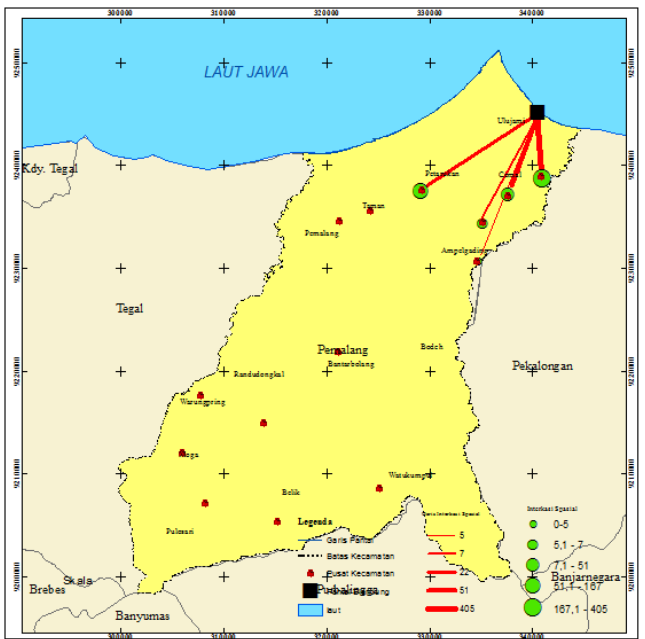

Fig 3. Spasial Interaction Pantai Blendung

The potential of Widuri Beach Tourism is higher than Blendung Beach Tourism. because Widuri Beach has more facilities around tourism and the strategic location of Widuri Beach. this can also be seen from access to very different beaches. Access to Widuri Beach is smooth and in good condition. while access to Blendung Beach is far from the main road and in poor condition.

\section{CONCLUSION}

From the results of the study it can be concluded that:

1. Based on the TCM variable table that affects the frequency of Widuri Beach visits is the cost. education. alternative locations and the number of groups. TCM variables that affect the frequency of Blendung Beach visits are cost, age, alternative locations and number of groups.

2. The value of TEV Widuri Beach with 110 respondent data is Rp. 34.850.465.345. Blendung Beach TEV value with 98 respondent data is Rp. 2.942.445.089. The TEV value of Widuri Beach is higher than Blendung Beach

3. The potential value of Widuri Beach Tourism is higher than Blendung Beach Tourism. It can be seen from the TEV value and interaction of Widuri Beach that is higher than Blendung Beach. The difference in spatial interactions can be seen from the different facilities available in Widuri Beach and easy access around Widuri beach. while Blendung Beach access road is quite difficult and further.

\section{SUGGESTIONS}

Suggestions that can be given to simplify and improve further research are as follows:

1. In searching for data. it is better to make the team finish faster.
2. Before conducting research. you should consider constraints and shortcomings in implementation.

3. The government should improve public facilities at Blendung Beach so that the potential of Blendung Beach increases and increases tourist comfort.

\section{REFERENCES}

[1] R. Al-Khoiriyah. Economic valuation using the Travel Cost Method in Pahawang Island Tourism Park. Pesawaran District. Journal of Agribusiness Science (JIIA). Lampung. vol. 5. no. 4 2018.

[2] B. Ariyadi. Analysis of morphological Patterns and Urban Spatial Interactions in Yogyakarta City with Wahana Citra Landsat. Journal of the University of Muhammadiyah Surakarta. 2014.

[3] C. Istighfary Abirama. Analysis of Regional Economic Values using the Travel Cost Method (TCM) and Contingent Valuation Method (CVM) for the making of a Zone Economic Value Zone map with GIS. Journal of Geodesy Undip. vol. 5. no.4. 2016

[4] I. Ghozali. Multivariate Analysis Application with SPSS Program. Semarang: Diponegoro University. 2011.

[5] Haslinda and J. Muhammad. Effect of budget planning and budget evaluation on organizational performance with cost standards as moderating variables in the Regional Government of Wajo Regency. Scientific Journal of Civilization Accounting. Makasar UIN Journal. vol.2 . no. 1. 2004

[6] R. Nasution. Sampling technique. University of North Sumatra Publication. 2003.

[7] S. Santoso. SPSS Parametric Statistics Exercise Book. Jakarta: Elex Media Komputindo. 2002

[8] S. A. B. Sitepu. Analysis of tourism development in the City of Semarang based on the value of frequency of visits from 20152017 with the approach of the Travel Cost Method and Contingent Valuation Method using GIS. Semarang: Thesis of Geodetic Engineering at Diponegoro University. 2017.

[9] S. Subiyanto and B. D. Yuwono. Analysis of Regional Economic Values development based on typology. frequency of visit and population using Geographic Information Systems to determine strategy development of Semarang City tourism area. 2019.

[10] Amalia. L. (2016). Analisis Komponen Daya Tarik di Kawasan Wisata Gunung Galunggung. Kecamatan Sukaratu. Kabupaten Tasikmalaya. Skripsi Universitas Gadjah Mada.

\{11\} S. Subiyanto. I. Maghda. and F. Amarrohman. Analysis of Regional Economic Values using Travel Cost Method (TCM) and contingent Valuation Method (CVM) for making zones of Economic Zones with GIS (Case Study: Semarang Old Town Area). 3rd CGISE paper and FIT-ISI. Yogyakarta. 2016.

[12] Supardi. Population and research samples. UNISIA research report. vol. 6. no.17. 1990. 